\title{
Asymmetric Information Games in Portrait of a Man, How Georges Perec Misleads his Reader and his Protagonist.
}

\author{
Clarisse Barbier \\ PhD candidate, University of Kansas, United States
}

\begin{abstract}
My paper will explore the question of misleading narrative in experimental and ludic author Georges Perec's very first novel Portrait of a Man. This novel offers a deep dive into the uninterrupted thought process of the protagonist, an art forger, as he tries to understand why he murdered a man. I will expose the different narrative strategies that are used by the author to playfully challenge the reader's navigation of the narrative, notably through the game-theory concept of asymmetric-information game (i.e. the information given by the author are incorrect or incomplete). I will also reveal how and why the protagonist unknowingly deceives himself in his perception of reality. Thanks to a close-reading approach and visualization tools, my research sheds new light onto this crucial novel in Perec's life work, as Portrait of a Man was published posthumously but paved the way to Perec's most famous and critically acclaimed works such as Life, a User's Manual or W, the Memory of Childhood. My paper, using notions of game-theory and cognitive narratology, brings new scholarship on a lesser known yet defining novel for Perec's career who eventually became a most influential author in the world of literature.
\end{abstract}

Keywords: narrative, Georges Perec, misleading, game theory 